\author{
Barbara CIECIŃSKA ${ }^{1}$ \\ Tomasz WIECEK ${ }^{2}$ \\ Ireneusz GACGAŁA ${ }^{3}$
}

\title{
LASERS IN INDUSTRY 4.0
}

\begin{abstract}
In this paper is presented the general idea of the industrial revolution which is called Industry 4.0. The main assumptions and an analysis of the laser use and requirements of lasers for flexible and agile production are presented. Examples of the different technological possibilities when lasers are joined with other machines and IT systems are described.
\end{abstract}

Keywords: lasers, Industry 4.0 conception, agile production

\section{INTRODUCTION}

In the past when the steam engine was invented and became implemented in typical everyday use, the world came into the first age of industrialization. In the factories and workshops the work stands were mechanized and use of the steam engine was in common practice. This was the first industrial revolution. Then together with electricity a new conception of joining together single work stands appeared, the work stands were connected into a production line and the production of products on an even greater scale became possible. This has been named Industry 2.0. The birth of computers and their popularization then gave the possibility of the development of companies on an unknown and previously unprecedented scale. Digitalization processes and the production of more and more efficient integrated circuits, and structures for data processing and control, gave the possibility of continuation of the factories development.

Digitalization, more effective data processing and control systems, and modern software made the production machines more efficient, precise, and added the possibility of connecting them for the creation of flexible production systems. Their integrative parts were both planning and control systems. Digitalization also

1 Corresponding author: Barbara Ciecińska, PhD, Eng., Rzeszow University of Technology, Faculty of Mechanical Engineering and Aeronautics, Powstancow Warszawy 8, 35-959 Rzeszow, e-mail: bcktmiop@prz.edu.pl

2 Tomasz WIĘCEK, DsC, Eng., Assoc. Prof., Rzeszow University of Technology, Faculty of Mathematics and Applied Physics, Powstancow Warszawy 6, 35-959 Rzeszow, e-mail: ftkwiece@prz.edu.pl

3 Ireneusz GĄGAŁA. MsC., TRUMPF Poland, ul. Połczyńska 111, 01-303 Warszawa, e-mail: Ireneusz.gagala@pl.trumpf.com 
allowed for a higher level of automatization, which was determinant in the technological development level $[1,2]$. This was the time of the third industrial revolution.

Nowadays production activity enters into the stage of Industry 4.0. The assumption behind Industry 4.0 is the integration of different systems and the creation of a network connecting people with machines. The flow of information is designed to go through the various components of the company and the IT department (vertically), and between the machines and the production system (horizontally) [3].

\section{THE PLACE OF LASER TECHNOLOGY IN INDUSTRY 4.0}

In this section we introduce the concept of industry in the age of computers and robots, where the areas of the plant activity are supported by intelligent systems capable of decision making and automatization. In this concept there are several areas concerning the functioning of plants, such as [3]:

- software - as a tool of integration of different functions,

- collecting and processing of data in the Cloud - which gives possibility of the analysis and decision making based on a huge amount of data stored in one place, available for many people in the same time,

- problems concerning cyber-security,

- artificial intelligence,

and many others relating to the comprehensive computerization of processes and data flow on an unprecedented scale.

The fundamental changes affecting the production and technological aspects of industry are related to an approach to customer and realization of its orders. Till recent times mass production was fundamental. Now the approach is completely changed - the industry has the need to be flexible for individual customer orders. This flexibility is possible thanks to computerized techniques. In the context of flexibility for individual customers the production is called "agile" [4]. In the Fig. 1 is shown the example of the order of one product for one customer. The typical production documents are not required. Tools and machines are selected by the software and saved in memory of the computer, time of production is also calculated.

The laser technology has the potential of making improvements in Industry 4.0. Many producers of lasers implemented new forms of collaboration between customers and system providers. Laser is only the element for performing the machining. The machines equipped in the laser head have possibility of combined technological operations preparation. Then the connection of the modern laser machining and typical, conventional technology (cutting, drilling, thread forming, welding, etc.) with time of carrying out reduction is possible [5]. 
Technological operations are planned and conducted with the usage of the additional equipment for parts sorting, feeding devices with robots and rational organization of the field of temporary parts storage. In the machines advanced optic systems, state sensors and control systems are required [6]. They give the possibility of data transfer about the state of the machine to the Cloud. Then the communication between machines is possible (Fig. 2.) [7, 8].

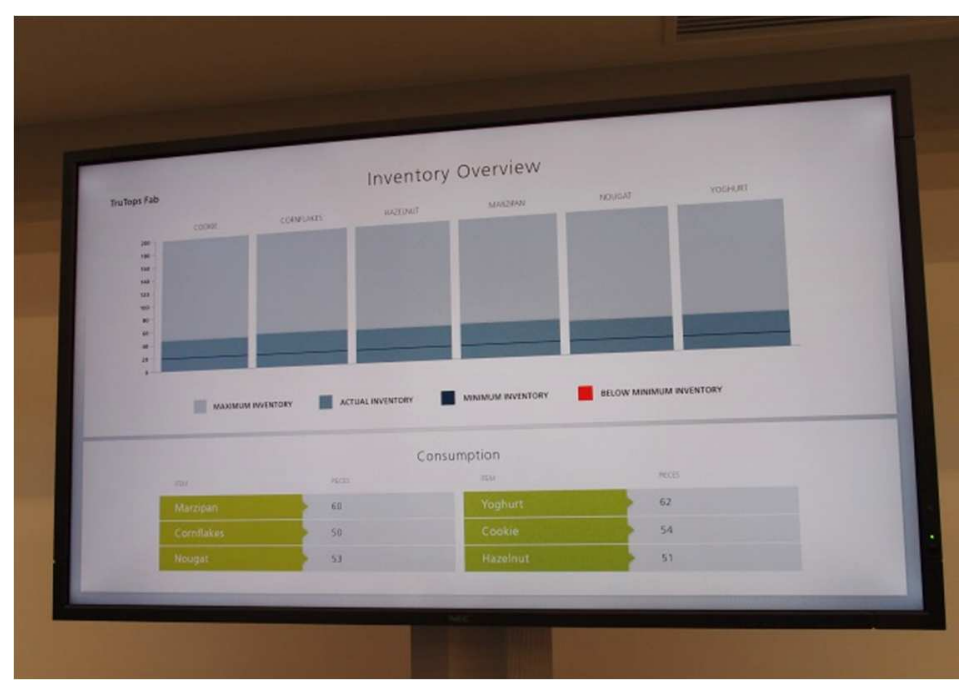

Fig. 1. Computerized possibility of individual product ordering

This solution is used in the flexible lines for laser cutting, marking or welding. Sometimes during the logical route of the technological operations a conventional machine appears, like a bending machine for example. Then the produced part does not leave the technological line. Another solution in the laser application is the creation of multi-head systems, which can be used in the selective laser manufacturing in the 3D production area [9].

An additional problem is individual customer order definition from the reason, that properties of the part should be transformed to the machine software language without the errors (the loss of the colors, thickness as the characteristics of the material is possible). At present it is verified and corrected on-line thanks to advanced computerized systems (Fig. 3).

Many producers of laser systems equipped their own production cells with the software for connecting machines. Mass individualization of the production is visible in the SMART industries, where the laser technique is widely used. It has a competitive advantage because of the shorter time of parts manufacturing than in conventional machining, the easiness of cleaning and safety. 
a)

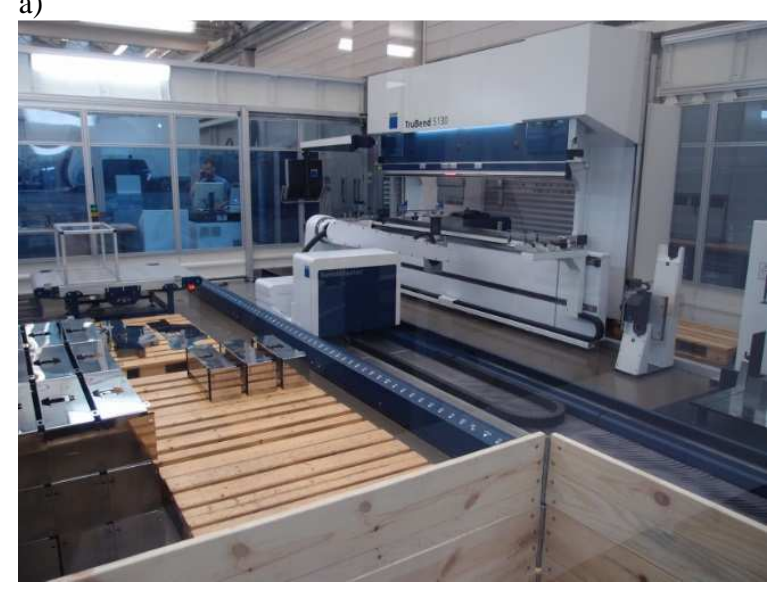

c)

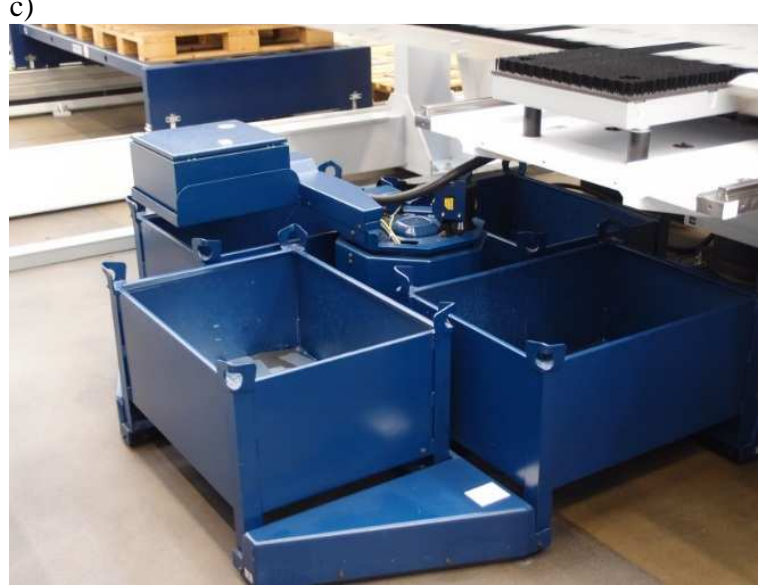

b)

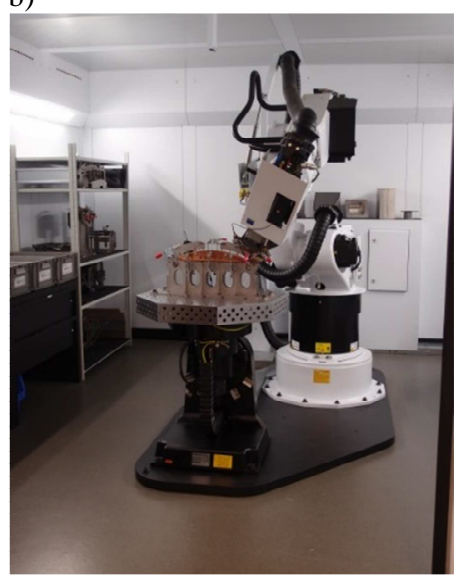

d)

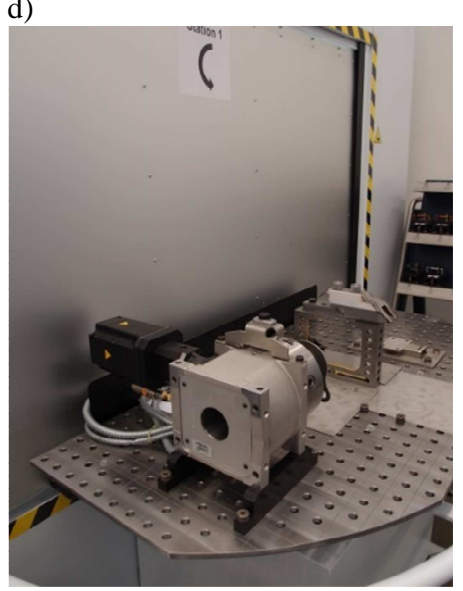

Fig. 2. Combined machines: a) advanced production cell for laser cutting, b) the work stand for laser welding with robots, c) the organization of the work stand for sorting and storage, d) the table with the other part outside of the laser treatment zone, concurrent machining inside the cabin is possible

Lasers are also used for the marking of parts because of the necessity of the fast parts navigation in the treatment space. The part should have individual properties, so it should be possible to tell one from another. Lasers enable the fast encoding of parts for traceability, order number, and quality control [10]. Laser marking is joined also with easy-to-install components like PC, electronics, beam sources, and optics. 


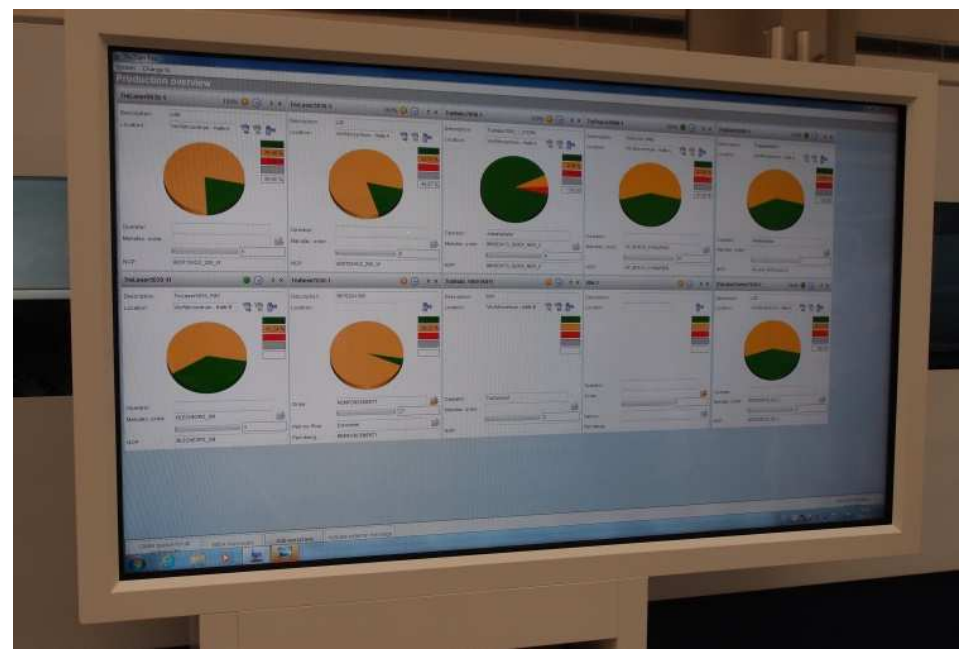

Fig. 3. Control on-line of the production state

\section{CONCLUSIONS}

The diversity of the possible applications of lasers gives a wide range of ways of preparing for integrated, flexible production lines, which can be competitive due to agility in adapting to customer order.

Lasers give the possibility not only for the replacement of typical, conventional work stands, eg. for cutting and engraving, but they can also be a complex manufacturing solution for the identification of the product, its measurement and marking.

Additionally if one producer has the possibility to supply different technological solutions with tailored software, portable and compact, then it can be deliver to the whole plant, where the manufactured assortment follows from customers' orders.

\section{Acknowledgement}

The authors would like to thank TRUMPF Poland for giving the possibility of conducting the research and preparing the paper.

\section{REFERENCES}

[1] Łunarski J.: Zarządzanie technologiami. Ocena i doskonalenie. Oficyna Wydawnicza Politechniki Rzeszowskiej, Rzeszów 2009.

[2] www.przemysl-40.pl

[3] Stadnicka D., Zielecki W., Sęp J.: Koncepcja przemyst 4.0 - ocena możliwości wdrożenia na przyktadzie wybranego przedsiębiorstwa. Konferencja Innowacje w Zarządzaniu i Inżynierii Produkcji, Zakopane 2017, http://www.ptzp.org.pl/ files/konferencje/kzz/artyk_pdf_2017/T1/t1_472.pdf 
[4] What a Website!, Impulse, 2016, No. 19, pp. 8-11.

[5] Maszyna laserowa $z$ dodatkowymi funkcjami. TruMatic 1000 fiber. Materiały TRUMPF Polska.

[6] Industry 4.0: Benefit From Opportunities. Today. Tomorrow. Laser Technik Journal, 5/2017, pp. 12-14.

[7] i4.0. Hunters of hidden treasure. Laser Community. Of people and photons. 2017, No. 25, p. 26.

[8] Networking with Partners Is Essential for Industry 4.0. Laser Technik Journal, 2017, No. 4, pp. 14-15.

[9] Dini C.: Why Beam Analysis is Crucial for Additive Manufacturing. Laser Technik Journal. 2018, No. 1, pp. 35-37.

[10] i4.0. Dumb parts in a smart factory. Laser Community, 2018, No. 26, p. 28.

\section{LASERY W KONCEPCJI PRZEMYSŁU 4.0}

W pracy przedstawiono ogólną koncepcję rewolucji przemysłowej nazywanej „Przemysł 4.0”. Opisano jej podstawowe założenia oraz przeanalizowano zastosowania laserów w kontekście wymagań elastycznej i zwinnej produkcji. Przedstawiono przykład różnorodnych możliwości technologicznych, jakie dają lasery wspomagane innymi obrabiarkami oraz systemami informatycznymi.

Słowa kluczowe: lasery, koncepcja Przemysł 4.0, zwinna produkcja

DOI: 10.7862/rf.2018.pfe.2

Received 28.06.2018

Accepted 12.09.2018 